\title{
PSYWAR - VIRTUÁLIS (LÉLEKTANI) LÖVÉSZÁROK KÉSZÜLT AZ „INNOVÁCIÓS STÚDIUM 2020/2021” PROJEKT KERETÉBEN
}

\section{Szerzők:}

Mező Ferenc (PhD)

Eszterházy Károly Katolikus Egyetem

Mező Kristóf Szíriusz

Kocka Kör

Mező Péter Dániel

Kocka Kör

\section{Lektorok:}

Kelemen Lajos $(\mathrm{PhD})$

Okoskocka Kft.

Nemes Magdolna (PhD)

Debreceni Egyetem

Első szerző e-mail címe:

ferenc.mezo1@gmail.com

...és további két anonim lektor

\section{Absztrakt}

A magyar Nemzeti Tehetség Program támogatta a $\mathrm{K}+\mathrm{F}$ Stúdió Kft. „Innovációs Stúdium 2020/2021” projektjét. E projekt keretében (többek között) „PSYWAR” címú virtuális kiállítás is készült. Ennek három fő tematikai egysége: 1) A pszichológiai hadviselés alapfogalmai és története, 2) az emberi szükségletek és a PSYWAR, és 3) a az attitűdökre irányuló PSYWAR.

Kulcsszavak: Psywar, tehetség, virtuális kiállítás

Diszciplina: Pszichológia, Pedagógia, Informatika, Hadtudomány

\section{Abstract}

A VIRTUAL (PSYCHOLOGICAL) TRENCH WAS MADE

IN THE FRAMEWORK OF THE INNOV ATION STUDIO 2020/2021 PROJECT

The Hungarian National Talent Program supported the project "Innovációs Stúdium 2020/2021" of K+F Stúdió Ltd. In the frame of this project (among others), a virtual exhibition entitled "PSYWAR" was made. Its three main thematical units are 1) Base concepts and history of Psychological Warfare, 2) Human Needs and PSYWAR, and 3) PSYWAR toward to Attitudes.

Keywords: Psywar, Talent, Virtual Exhibition

Discipline: Pschology, Pedagogy, Informatics, Military Science

Mező Ferenc, Mező Kristóf Szíriusz és Mező Péter Dániel (2021): PSYWAR - Virtuális (lélektani) lövészárok készült az Innovációs Stúdium 2020/2021 projekt keretében. Lélektan és hadviselés - interdiszciplináris folyóirat, III. évf. 2021/1. szám. 97-101. doi: 10.35404/LH.2021.1.97 
A 2020/2021. évben valósul meg a $\mathrm{K}+\mathrm{F}$ Stúdió Kft. „Innovációs Stúdium 2020/ 2021" című tehetséggondozó projektje a Nemzeti Tehetség Program támogatásával (a pályázat azonosító száma: NTP-PKTF-20-0009 - v.ö.: 1. ábra).

1. ábra: az Innovációs Stúdium 2020/ 2021 projekt támogatói. Forrás: a Szerzók

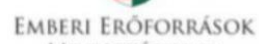

MINISZTERIUMA

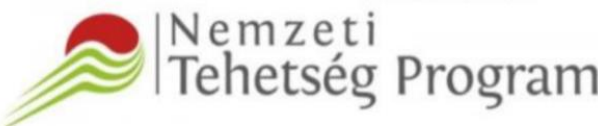

E projekt keretében megvalósuló egyik innovatív elem a „PSYWAR - kiállítás a lélektani hadviselésről" című virtuális produkció (2. ábra - web: www.kpluszf.com).

2. ábra: a PSYWAR kiállitás plakátja. Forrás: a Szerzók

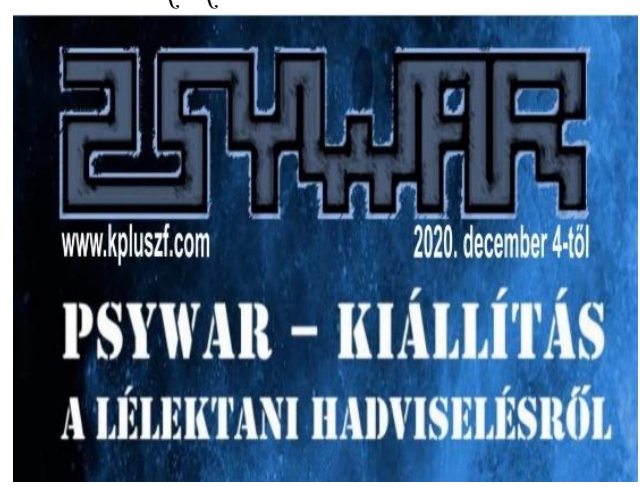

A 2. ábrán látható PSYWAR felirat egyben a virtuális lövészárok alaprajza, ami a P-betű felső, nyitott részétől az R-betű száráig terjedő út járható be.

A kiállítás célja: a lélektani hadviseléssel kapcsolatos ismeretterjesztés a hadtörténet és a pszichológia iránt érdeklődők számára. A lélektani hadviseléssel kapcsolatban magyar nyelven lásd: Bolgár (2005), Pix (2005), Mező (2014), Mező és Mező (2019).

A kiállítás kurátora: dr. Mező Ferenc; a szoftvertfejlesztő: Mező Kristóf Szíriusz.

Ár: a kiállítás megtekintése ingyenes.

Ajánlott korosztály: 12 éves kortól.

Eszközszükséglet: billentyűzettel és egérrel rendelkező számítógép.

A kiállítás három főbb tartalmi egységre tagolható, ezek:

1. A lélektani hadviselés alapjai, története és klasszikus (brit, francia, szovjetúnióbeli és USAbeli) szervezetei (3. ábra). Ebben a részben tekinthetik át továbbá a látogatók az üzenetközlésen keresztül (is) ható lélektani hadviselés kommunikációs eszköztárának történelmi alakulását az őskortól napjainkig terjedő intervallumban - a non-verbális kommunikáció őskori lehetőségeitől a beszéden, majd íráson alapuló verbális kommunikáción, továbbá az egyre fejlettebb technológiai lehetôségeken (mint például nyomtatás, fénykép, hangrögzítés, mozgófilm készítés, rádiós és televíziós műsorközlésen) át a napjaink internet kultúrájáig.

2. A humán szükségleteken alapuló lélektani hadviselés (4. ábra). A lélektani hadviselési célok elemzése, tervezése kapcsán is 
3. ábra: részlet a PSYW AR kiállitás lélektani hadviselés alapjait, történetét és klasszilkus szervezeteit bemutató egységéböl. Forrás: a Szerzőók.

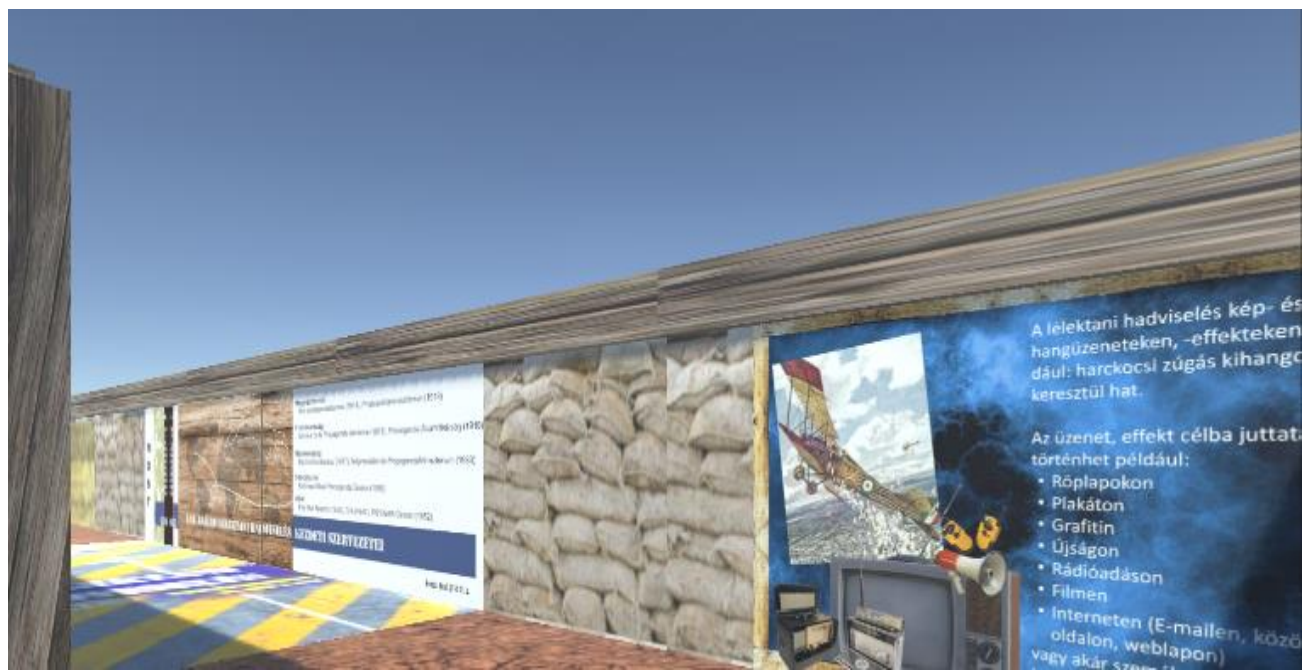

4. ábra: részlet a PSYWAR kiállitás humán szükeségletekkel kapcsolatos (had)történeti példákat bemutató tablóiból. Forrás: a Szerzőók.

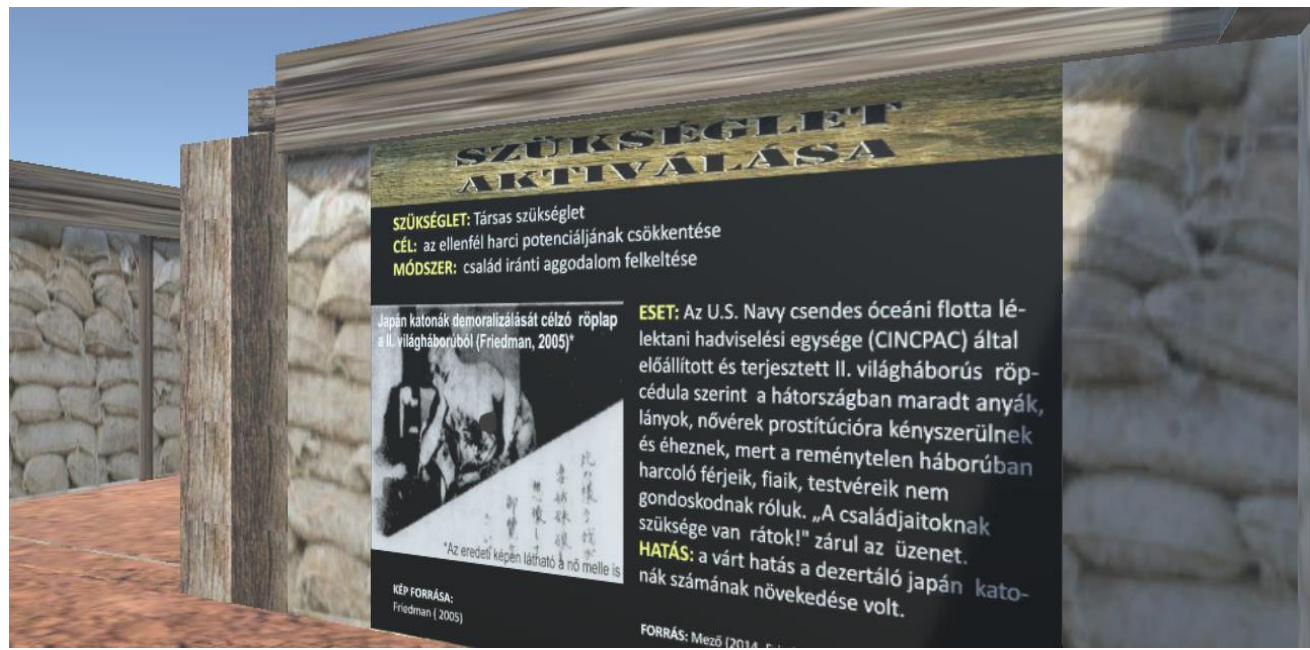


gyakran felmerülő (ám korántsem ilyen célból készült) Maslow-féle szükséglet-hierarchia elmélet (Maslow, 1988) rövid vázolásán túl, a látogatók megismerhetik a szükségletek aktiválásának (felkeltésük-nek és/vagy kielégítésük megakadályozásának) és deaktiválásának (kielégítésüknek és/vagy felkeltésük megakadályozásának) néhány történelmi példáját a fiziológiai, a biztonsági, a szociális, a tisztelet- és önbecsülés iránti igény, és az önmegvalósítás iránti szükséglet tekintetében.
3. Az attitűdökre irányuló lélektani hadviselést bemutató szekció. Az attitűdök a tárgyukkal - például az ellenséggel, a háborúval, a békével stb. - kapcsolatos ismeretek, emóciók és viselkedési szándékok összesssége. Lélektani hadviselési szempontból cél lehet egy-egy témával kapcsolatos attitűd kiváltása, megváltoztatása, vagy éppen ezek megakadályozása. A PSYWAR virtális kiállításon többek között az attitűdökkel kapcsolatos műveletekre is láthatunk hadtörténeti példákat (5. ábra).

5. ábra: részlet a PSYWAR kiállitás attitüdökkel kapcsolatos (had)történeti példákat bemutató szegmenséböl. Forrás: a Szueroő́k.

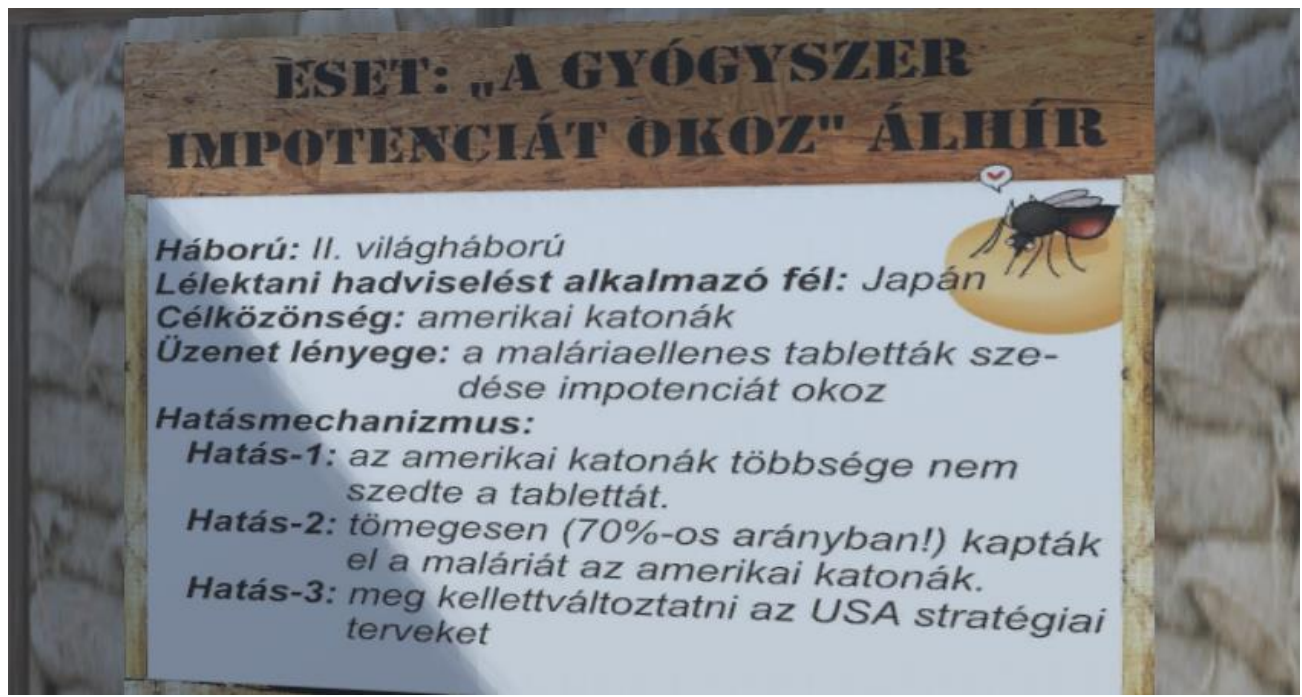

A kiállítás zárásaként a látogatók figyelmébe ajánlott fontos üzenet, hogy a „A lélektani hadviselés önmagában nem jó vagy rossz: a felhasználók szándékaitól függ, hogy a béke nem halálos, ám erôsokszorozó hatású fegyvere, vagy alantas szándékok eszköze lesz-e.” (6. ábra). 
6. ábra: a PSYW AR kiállitás zárótablója. Forrás: a Szerzóke

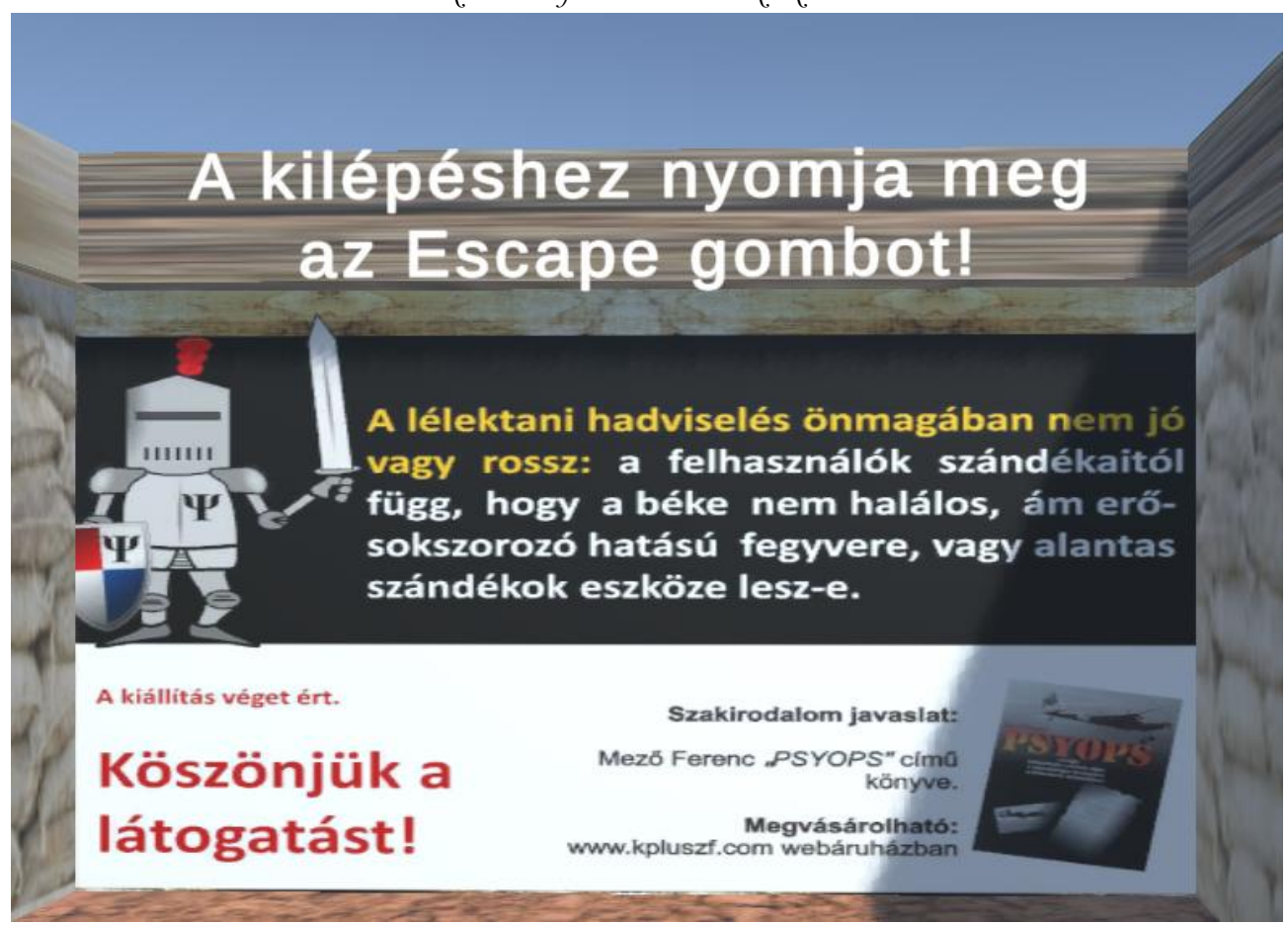

\section{Irodalom}

Bolgár J. (2005): A lélektani műveletek pszichológiai alapjai. Humán Szemle, XXI. évf. 2005/2.; 74-80. pp.

Maslow, A. H. (1988): Elmélet az emberi motivációról. In: Oláh A. és Pléh Cs. (szerk.): Szöveggyüjtemény az általános és a személyiségpszichológiához:

Tankönyvkiadó, Budapest. 373-392.

Mező F. (2014): PSYOPS - avagy: kalandozás a badak útján, a pszichológia ösvényein, a történelem útvesztöiben. Kocka Kör, Debrecen
Mező F. és Mező K. (2019): Lélektan és hadviselés. Lélektan és hadviselés interdiszciplináris folyóirat, I. évf. 2019/1. szám. 9-25. doi: 10.35404/LH.2019.1.9

Pix G. (2005): A lélektani müveletek. jellem röinek vizsgálata. Doktori (PhD-) értekezés. Készült a Zrínyi Miklós nemzetvédelmi Egyetem, Hadtudományi Doktori Iskola keretében. Letöltés: 2014.01.30. Web: http:/ / uninke.hu/downloads/konyvtar/digitgy/ phd/2006/pix_gabor.pdf. 